\title{
Effect of Micro Nutrient Management in Hybrid Sunflower on Growth and Yield
}

\author{
V. Ramesh ${ }^{1 *}$, J. Manjunath $^{1}$, M. Saravanaperumal ${ }^{2}$ and Reddy Bheemanna ${ }^{3}$ \\ ${ }^{1}$ DAATTC, KVK, Undi, West Godavari (dist.) Andhra Pradesh, India \\ ${ }^{2}$ Annamalai University, Tamil Nadu, India \\ ${ }^{3}$ KVK, Banavasi Kurnool (dist.) Andhra Pradesh, India \\ *Corresponding author:
}

\begin{abstract}
A B S T R A C T
\section{Keywords}

Foliar spray, Micro nutrient, RDF,

Hybrid sunflower growth

\section{Article Info}

Accepted:

10 May 2019

Available Online:

10 June 2019

A field experiment was conducted at Annamalai university experimental farm Chidambaram during kharif 2014 to study the effect of micro nutrient management in hybrid sunflower on growth and yield. Application of 150\% RDF (60:90:60 kg NPK ha ${ }^{-1}$ ) along with micro nutrient @250 $\mathrm{g} \mathrm{ha}^{-1}$ at 25 \&45 days after sowing, recorded higher plant height $(64.88,145.26$ and 166.24$)$ at 30,60 and harvest stage, respectively over control. Similar trends was also noticed in days to 50 per cent flowering (56.05), early where notice application of 150 per cent RDF + foliar spray of micro nutrient @250 $\mathrm{g} \mathrm{ha}^{-1}$ at $25 \& 45$ days after sowing, recorded higher yield attributes and yield data like capitulum ${ }^{-1}$ diameter $^{-1}$ $(20.85 \mathrm{~cm})$, total number of seeds for capitulum ${ }^{-1}$, (1040.96) filled seeds for capitulum ${ }^{-1}$ (925.25), per Cent of filled seed for capitulum ${ }^{-1}$ (88.88), test weight (5.9), seed yield $\left(2195.3 \mathrm{~kg} \mathrm{ha}^{-1}\right)$, stalk yield $\left(3556.3 \mathrm{~kg} \mathrm{ha}^{-1}\right)$ and harvest index $(38.16 \%)$ over control. The quality parameters were also recorded significant higher oil content (43\%) and oil yield (943.97 $\mathrm{kg} \mathrm{ha}^{-1}$ ) over control. And benefit cost ratio (3.12) recorded. Following with 125 $\% \mathrm{RDF}+$ foliar spray of micro nutrient @ $250 \mathrm{~g} \mathrm{ha}^{-1}$ at 25 and 45 days after sowing.
\end{abstract}

\section{Introduction}

Sunflower (Helianthus annuus L.) is an important oil seed crop of the world and it ranks third in production next to groundnut and soybean. In India oil seeds crop occupy an area of 32.4 million hectares with 28.2 million tonnes of production registering a productivity levels of $1041 \mathrm{~kg} \mathrm{ha}^{-1}$. About 14 million persons are engaged in production and another one million in processing of oil seeds (Sonnad et al., 2011). At present the annual edible oil requirement of the country is about 18.24 million tonnes of which only 8.04 million tonnes are met by local production and rest 9.34 million tonnes is being imported. The total world production of sunflower during 2012-13 amount to approximately 36.36 million tonnes. In India during 2012-13 sunflower is cultivated in area of 2.34 million hectare with a production of 11.61 lakhs tonnes with average productivity of $615 \mathrm{~kg} \mathrm{ha}^{-1}$. In Tamil Nadu during 2012-13 sunflower is grown in an area of 20000 
hectare with a production of 30000 tonnes with average productivity of $1746 \mathrm{~kg} \mathrm{ha}^{-1}$. Among the various micronutrient iron is critical for chlorophyll formation and photosynthesis and is important in the enzyme systems and respiration of plants. Manganese is an essential nutrient that required for the hill reaction the water splitting and oxygen evolving system in photosynthesis. Photosystem II contains a manganoan protein which catalyses the early stage of $\mathrm{O}_{2}$ evolution (Nusrat Jabeen and Rafiq Ahmad., 2011). Foliar spray of zinc and molybdenum levels resulted in increasing plant height number of fruit yield. Boron is involved in many process including sugar transport, cell wall synthesis and maintenance, membrane integrity and RNA indole acetic acid (IAA) and phenolic metabolism (Loomis and Durst., 1992; Dordas and Brown., 2011). Foliar feeding of nutrients has become an establishment procedure to increase yield and improve the quality of crop production. This procedure improves nutrient utilization and lower environment pollution through reducing amount of fertilizers added to soil. Foliar feeding of nutrients many actually promote root absorption of the same nutrient or other nutrient through improving root growth. The lower productivity of sunflower is mainly due to lack of high yielding varieties, its cultivation on marginal lands with inadequate nutrients, non-adoption of proper crop rotation and weed management practices and also continuous use of inorganic fertilizer deteriorates, soil health and also which makes soil unproductive for next season. Hence, there is an urgent need to use different combination of organics and inorganics along with micronutrient.

\section{Materials and Methods}

\section{Experimental site}

Field experiment was conducted at the experimental farm department of Agronomy, faculty of Agriculture, Annamalai University, Annamalai Nagar during kharif 2014, to study the Effect of micro nutrient management in hybrid sunflower on growth and yield. It was laid out in randomized block design with three replications and consisted of 10 different treatments.

\section{Field preparation and fertilizer application}

The experimental field was ploughed with tractor mounted cultivators to bring the soil to a fine tilth conditions the field was levelled after the clouds were broken. Fertilizer were incorporated in furrows as per the treatments before sowing and entire quantity of $\mathrm{P}_{2} \mathrm{O}_{5}$ and $\mathrm{K}_{2} \mathrm{O}$ (DAP and muri ate of potash) as basal dose to the hybrid sunflower, $50 \%$ of nitrogen applied as basal and remaining $50 \%$ applied as top dressing through urea. Soil application of micro nutrient $20 \mathrm{~kg} \mathrm{ha}^{-1}$ was applied at the time of seed sowing as per treatment schedule and foliar application of micro nutrient was applied $250 \mathrm{~g} \mathrm{ha}^{-1}$ at 25 and 45 DAS as per the treatment schedule with knapsack sprayer.

\section{Growth attributes}

Five plants per plot were selected randomly and tagged in the net plot area for recording observation on the growth attributes. The plant height was measured from the base of the plant at ground level to the point of attachment of the capitulum ${ }^{-1}$ at 30,60 and harvest stage and express in centimetre. Seedling dry weight was recorded by keeping 5 normal seedlings in a hot air oven maintained at $80^{\circ} \mathrm{c}$ till constant weight was obtained the values were expressed in $\mathrm{kg} \mathrm{ha}^{-1}$.

\section{Yield attributes and yield}

The capitulum ${ }^{-1}$ diameter was measured by taking distance between diagonally opposite edges of the capitulum $^{-1}$ and express in centimetre. The per cent seed filling per 
capitulum $^{-1}$ was calculated by using the following formula.

Per cent of filled seeds capitulum ${ }^{-1}=$

Number of filled seeds $* 100$

Total number of seeds head

The seed yield was recorded net plot wise and converted into per hectare basic and express as $\mathrm{kg} \mathrm{ha}^{-1}$

The harvest index was calculated by using the formula, suggested by Verma (1973).

Harvest index $=$

$\underline{\text { Seed yield } \mathrm{x} 100}$

Biological yield

\section{Quality parameters}

The oil content of seeds was estimated using commercial nuclear magnetic resonance spectrometer (NMRS) method following the procedure described by Jambunuthan et al., (1985) and expressed in per cent. The oil yield was worked out by multiplying the oil content with seed yield and expressed in $\mathrm{kg}$ $\mathrm{ha}^{-1}$.

\section{Results and Discussion}

\section{Growth parameters}

The growth parameters all the treatments showed non-significant variation at 30 DAS on the plant height of sunflower. All the treatments showed significant variation at different growth stages viz., 60 DAS and at harvest stages during the cropping season. Among the treatments, the application of 150 $\%$ RDF +foliar spray of micro nutrient @ 250 $\mathrm{g} \mathrm{ha}^{-1}$ at $25 \& 45 \mathrm{DAS}\left(\mathrm{T}_{10}\right)$ had registered the highest plant height on 60 DAS and harvest stages with $145.26 \mathrm{~cm}$ and $166.24 \mathrm{~cm}$ respectively. This was followed by other treatments viz., $125 \%$ RDF + foliar spray of micro nutrient@250 $\mathrm{g} \mathrm{ha}^{-1}$ at 25 \& 45 DAS $\left(\mathrm{T}_{9}\right)$. This was on par with $150 \% \mathrm{RDF}+$ soil application of micro nutrient @ $20 \mathrm{~kg} \mathrm{ha}^{-}$ ${ }^{1}\left(\mathrm{~T}_{7}\right)$. This was followed by $100 \% \mathrm{RDF}+$ foliar spray of micro nutrient @ $250 \mathrm{~g} \mathrm{ha}^{-1}$ at $25 \& 45$ DAS $\left(\mathrm{T}_{8}\right)$. This was on par with 125 $\%$ RDF + soil application of micro nutrient @ $20 \mathrm{~kg} \mathrm{ha}{ }^{-1}\left(\mathrm{~T}_{6}\right)$ and $100 \% \mathrm{RDF}+$ soil application of micro nutrient @ $20 \mathrm{~kg} \mathrm{ha}^{-}$ ${ }^{1}\left(\mathrm{~T}_{5}\right)$. This was followed by application of $150 \% \operatorname{RDF}\left(\mathrm{T}_{4}\right), 125 \% \mathrm{RDF}$ and $100 \%$ $\operatorname{RDF}\left(\mathrm{T}_{2}\right)$. The least plant height of 44.12 , 103.08 and $112.8 \mathrm{~cm}$ at 30, 60 and harvest stages, respectively were recorded under control $\left(\mathrm{T}_{1}\right)$. This clearly indicates the need for adding micro nutrient to the soil in conjunction with macro nutrient, which increase the availability nutrient considerably resulting in positive effect on growth parameters. The similar finding where notice by Venkata Krishnan and Balasubramanian (1996). Reported that plant height, LAI and DMP of sunflower increased with foliar spray of 0.2 per cent borax and application of @ 25 $\mathrm{kg} \mathrm{ha}{ }^{-1}$. Copper is involved in number of physiological processes such as the photosynthetic and respiratory electron transport chains and as a cofactor or as a part of the prosthetic group of many key enzymes involves in different metabolic pathways, including ATP synthesis (Harrison et al., 1999). The dry matter production was significantly influenced by the application of $150 \%$ RDF + foliar spray of micro nutrient @ $250 \mathrm{~g} \mathrm{ha}^{-1}$ at $25 \& 45 \mathrm{DAS}\left(\mathrm{T}_{10}\right)$ which registered the maximum dry matter production on 60 DAS and harvest stages with 3700.23 and $5061.54 \mathrm{~kg} \mathrm{ha}^{-1}$. This was followed by the $\left(\mathrm{T}_{9}\right),\left(\mathrm{T}_{7}\right),\left(\mathrm{T}_{8}\right),\left(\mathrm{T}_{6}\right),\left(\mathrm{T}_{5}\right)$, $\left(\mathrm{T}_{4}\right)$, $\left(\mathrm{T}_{3}\right)$, $\left(\mathrm{T}_{2}\right)$. The least dry matter production of 250.04, 1626.37 and 2261.54 $\mathrm{kg} \mathrm{ha}^{-1}$ at 30, 60 DAS and harvest stages, were recorded under $\left(\mathrm{T}_{1}\right)$ control. Foliar mineral spray significantly effects biomass 
production of plants irrespective to their growth under non-saline or saline conditions. Ali and Mowafy (2003) reported that foliar application of $\mathrm{Zn}(2 \%)$ reported maximum plant DMP over control. Foliar application of minerals like iron, boon, manganese and copper may be more practical then application to soil particles and less available to the rooting medium (Sarkar et al., 2007). The observation recorded on the number of days to fifty per cent flowering among the treatments, application of $150 \% \mathrm{RDF}+$ foliar spray of micro nutrient @ $250 \mathrm{~g} \mathrm{ha}^{-1}$ at $25 \&$ $45 \mathrm{DAS}\left(\mathrm{T}_{10}\right)$ had recorded 56.52 days to fifty per cent flowering and it was followed by the $\left(\mathrm{T}_{9}\right),\left(\mathrm{T}_{7}\right),\left(\mathrm{T}_{8}\right),\left(\mathrm{T}_{6}\right),\left(\mathrm{T}_{5}\right),\left(\mathrm{T}_{4}\right),\left(\mathrm{T}_{3}\right),\left(\mathrm{T}_{2}\right)$. The number of days (60.05) to fifty per cent flowering was recorded under $\left(\mathrm{T}_{1}\right)$ control.

Foliar application of zinc leads to reduce the days to fifty per cent flowering in sunflower over other treatments (Faizu Saliphin and Shahzad Rahman, 2012). Muhammad Tahir et al., (2013) revealed that foliar application significantly reduced the number of days to fifty per cent flowering in sunflower over other treatments. Among all the treatments, the application of $150 \% \mathrm{RDF}+$ foliar spray of micro nutrient @ $250 \mathrm{~g} \mathrm{ha}^{-1}$ at $25 \& 45$ DAS $\left(\mathrm{T}_{10}\right)$ had a remarkable influence on growth characters the production of vigorous plants due to the synergetic and cumulative effect of micro nutrient could be the reasons for better performance of sunflower in terms of plant height, dry matter production and days to fifty percent flowering. All the growth components viz., plant height, leaf area index, dry matter production and days to fifty percent flowering recorded an increased value than the recommended levels of NPK. This finding is in conformity with the results of Ayadshankersaad and Mohammed (2011), who obtained the maximum plant height, dry matter production leaf area index and days to fifty percent flowering in sunflower by the application of higher levels of NPK. These similar inference were documented by Chinnamuthu et al., (2004) and Murali Arthanari et al., (2009). Micro nutrient foliar application having key role in nitrogen uptake and principle catalyst in reduction of nitrates to ammonia in protein synthesis; it also enhances the nitrogen use efficiency of higher plants. Might have higher uptake of nitrogen by sunflower resulting in greater plant height at different stages of crop growth compared to recommended NPK + micro nutrient soil application. The availability of micro nutrients allow crop plant to carry out normal physiological process for photosynthetic assimilates productivity and its storage in sink (Sivakumar et al., 2003). This might be the reason for higher dry matter production and growth indices than recommended NPK + soil application micronutrient (Table 1).

\section{Yield attributes and yield}

The yield parameters were different significantly due to treatments. The higher capitulum $^{-1}$ diameter $(20.85 \mathrm{~cm})$ was noticed in application of $150 \% \mathrm{RDF}+$ foliar spray of micro nutrient@250g ha ${ }^{-1}$ at 25 \& 45 DAS $\left(\mathrm{T}_{10}\right)$ which was statistically on par with $125 \% \mathrm{RDF}+$ foliar spray of micro nutrient @ $250 \mathrm{~g} \mathrm{ha}^{-1}$ at 25 and 45 DAS $\left(\mathrm{T}_{9}\right)$ which was on par with $\left(\mathrm{T}_{7}\right)\left(\mathrm{T}_{8}\right)\left(\mathrm{T}_{6}\right)\left(\mathrm{T}_{5}\right)\left(\mathrm{T}_{4}\right)\left(\mathrm{T}_{3}\right)\left(\mathrm{T}_{2}\right)$. Whereas lowest capitulum diameter with $\left(\mathrm{T}_{1}\right)$ control $(10.12 \mathrm{~cm})$ the increase in capitulum diameter in $\left(\mathrm{T}_{10}\right)$ was mainly due to the higher nutrient availability which enhances the size of the capitulum. Total number of seeds capitulum, number of filled seeds capitulum, percentage of filled seeds capitulum, test weight seed yield stalk yield and harvest index where also higher in $\left(\mathrm{T}_{10}\right)$ treatments (1040.65,925.63, 88.88, $5.9 \mathrm{~g}, 2195.3 \mathrm{~kg} \mathrm{ha}^{-1}$, $3556.48 \mathrm{~kg} \mathrm{ha}^{-1}$ and 38.16 respectively). Which was on par with $\left(\mathrm{T}_{9}\right)\left(\mathrm{T}_{7}\right)\left(\mathrm{T}_{8}\right)\left(\mathrm{T}_{6}\right)\left(\mathrm{T}_{5}\right)$ $\left(\mathrm{T}_{4}\right)\left(\mathrm{T}_{3}\right)\left(\mathrm{T}_{2}\right)$.Which directly increase crop yield by supplying major and micro nutrients this result are in accordance with the finding 
obtained by Khurana and Chatterjee (2001) reported that the number of seeds per head and thousand seeds weight of sun flower were highest when zinc was sufficient. Renukadevi et al., (2004) observed that application of B at
$2.0 \mathrm{~kg} \mathrm{ha}^{-1}$ significantly increased the seed yield of sunflower by 16 per cent increase in leaf dry matter with $\mathrm{B}$ is in accordance with recommendation of $2.0 \mathrm{~kg} \quad \mathrm{ha}^{-1}$.

Table.1 Effect of micro nutrient management in hybrid sunflower on growth parameters

\begin{tabular}{|c|c|c|c|c|c|c|c|}
\hline \multirow[t]{2}{*}{ TREATMENTS } & \multicolumn{3}{|c|}{ Plant height (cm) } & \multicolumn{3}{|c|}{ Dry matter production $\left(\mathrm{kg} \mathrm{ha}^{-1}\right)$} & \multirow{2}{*}{$\begin{array}{l}\text { Days to fifty per } \\
\text { cent flowering }\end{array}$} \\
\hline & 30 DAS & 60 DAS & Harvest & 30 DAS & $60 \mathrm{DAS}$ & Harvest & \\
\hline T1- Control & 44.12 & 103.08 & 112.80 & 250.27 & 1626.37 & 2261.5 & 60.52 \\
\hline $\begin{array}{l}\text { T2- } 100 \% \text { RDF }(60-90-60 \mathrm{~kg} \\
\left.\text { ha }^{-1} \mathrm{~N}_{2} \mathrm{P}_{2} \mathrm{O}_{5} \text { and } \mathrm{K}_{2} 0\right)\end{array}$ & 58.16 & 113.40 & 117.60 & 579.02 & 2616.93 & 3320.28 & 58.24 \\
\hline T3- 125\% RDF & 61.24 & 118.52 & 124.20 & 631.71 & 2795.02 & 3697.18 & 58.03 \\
\hline T4- $150 \%$ RDF & 64.36 & 123.55 & 131.94 & 665.28 & 2996.8 & 4104.05 & 57.74 \\
\hline $\begin{array}{l}\text { T5- } 100 \% \text { RDF + soil } \\
\text { application of micro nutrient @ } \\
20 \mathrm{~kg} / \mathrm{ha}^{-1}\end{array}$ & 59.72 & 128.34 & 140.25 & 580.17 & 3183.88 & 4358.03 & 57.43 \\
\hline $\begin{array}{l}\text { T6-100 \% RDF + soil } \\
\text { application of micro nutrient @ } \\
20 \mathrm{~kg} / \mathrm{ha}^{-1}\end{array}$ & 62.50 & 131.13 & 144.41 & 632.40 & 3235.92 & 4441.12 & 57.16 \\
\hline $\begin{array}{l}\text { T7-100 \% RDF + soil } \\
\text { application of micro nutrient @ } \\
20 \mathrm{~kg} / \mathrm{ha}^{-1}\end{array}$ & 65.12 & 138.33 & 155.9 & 667.20 & 3465.69 & 4747.66 & 56.84 \\
\hline $\begin{array}{l}\text { T8-100 \% RDF + foliar spray of } \\
\text { micro nutrient @ } 250 \mathrm{~g} \mathrm{ha}^{-1} \text { at } 25 \\
\text { \& } 45 \text { DAS }\end{array}$ & 58.93 & 134.03 & 148.59 & 578.62 & 3270.7 & 4480.10 & 56.57 \\
\hline $\begin{array}{l}\text { T9-125\% RDF+ foliar spray of } \\
\text { micro nutrient @ } 250 \mathrm{~g} \mathrm{ha}^{-1} \text { at } 25 \\
\text { \& } 45 \text { DAS }\end{array}$ & 69.62 & 141.16 & 160.03 & 631.96 & 3533.14 & 4827.64 & 56.32 \\
\hline $\begin{array}{l}\text { T10-150 \% RDF + foliar spray } \\
\text { of micro nutrient @ } 250 \mathrm{~g} \mathrm{ha}^{-1} \text { at } \\
25 \& 45 \text { DAS }\end{array}$ & 64.88 & 145.26 & 166.24 & 665.98 & 3700.23 & 5061.54 & 56.05 \\
\hline S. Ed & - & 1.50 & 2.21 & - & 64.20 & 74.16 & 0.12 \\
\hline $\mathrm{CD}(\mathrm{P}=\mathbf{0 . 0 5})$ & NS & 3.19 & 4.52 & NS & 130.00 & 150.00 & 0.25 \\
\hline
\end{tabular}

$\mathrm{RDF}=$ recommended dose of fertilizer $\quad \mathrm{DAS}=$ days after sowing $\mathrm{N}=$ nitrogen
$\mathrm{P}_{2} \mathrm{O}_{5}=$ phosphorus

$\mathrm{K}_{2} \mathrm{O}=$ potash 
Table.2 Effect of micro nutrient management in hybrid sunflower on yield attributes and yield

\begin{tabular}{|c|c|c|c|c|c|c|c|}
\hline TREATMENTS & $\begin{array}{l}\text { Capitulu } \\
\mathbf{m}^{-1} \\
\text { diameter } \\
(\mathrm{cm})\end{array}$ & $\begin{array}{l}\text { Total } \\
\text { number } \\
\text { of seeds } \\
\text { capitulu } \\
\text { m }^{-1}\end{array}$ & $\begin{array}{l}\text { No. of } \\
\text { filled } \\
\text { seeds } \\
\text { capitulum- } \\
1\end{array}$ & $\begin{array}{l}\text { Per cent } \\
\text { of filled } \\
\text { seeds } \\
\text { capitulum- } \\
1\end{array}$ & $\begin{array}{l}\text { Test } \\
\text { weight(g) }\end{array}$ & $\begin{array}{l}\text { Seed yield } \\
\left(\mathrm{kg} \mathrm{ha}^{-1}\right)\end{array}$ & $\begin{array}{l}\text { Stalk yield } \\
\left(\mathrm{kg} \mathrm{ha}^{-1}\right)\end{array}$ \\
\hline T1- Control & 10.12 & 448.15 & 217.65 & 48.56 & 4.92 & 750.13 & 1620.83 \\
\hline $\begin{array}{l}\text { T2- } 100 \% \text { RDF }\left(60-90-60 \mathrm{~kg} \mathrm{ha}^{-}\right. \\
\left.{ }^{1} \mathrm{~N}_{2} \mathrm{P}_{2} \mathrm{O}_{5} \text { and } \mathrm{K}_{2} \mathrm{O}\right)\end{array}$ & 11.83 & 723.38 & 511.21 & 70.66 & 5.13 & 1491.63 & 2670.18 \\
\hline T3- 125\% RDF & 13.35 & 766.01 & 600.44 & 78.38 & 5.23 & 1610.86 & 2826.53 \\
\hline T4- $150 \%$ RDF & 14.31 & 818.37 & 659.07 & 80.53 & 5.34 & 1720.09 & 2978.18 \\
\hline $\begin{array}{l}\text { T5- } 100 \% \mathrm{RDF}+\text { soil } \\
\text { application of micro nutrient @ } \\
20 \mathrm{~kg} / \mathrm{ha}^{-1}\end{array}$ & 15.74 & 881.02 & 734.32 & 83.34 & 5.47 & 1830.65 & 3127.41 \\
\hline $\begin{array}{l}\text { T6-100 \% RDF + soil } \\
\text { application of micro nutrient @ } \\
20 \mathrm{~kg} / \mathrm{ha}^{-1}\end{array}$ & 16.39 & 907.54 & 762.32 & 84.00 & 5.55 & 1856.1 & 3168.97 \\
\hline $\begin{array}{l}\text { T7-100 \% RDF + soil } \\
\text { application of micro nutrient @ } \\
20 \mathrm{~kg} / \mathrm{ha}^{-1}\end{array}$ & 18.87 & 979.88 & 855.58 & 87.04 & 5.73 & 2034.34 & 3354.78 \\
\hline $\begin{array}{l}\text { T8-100 \% RDF + foliar spray of } \\
\text { micro nutrient @ } 250 \mathrm{~g} \mathrm{ha}^{-1} \text { at } 25 \\
\text { \& } 45 \text { DAS }\end{array}$ & 16.98 & 937.99 & 793.13 & 84.55 & 5.61 & 1881.22 & 3210.53 \\
\hline $\begin{array}{l}\text { T9-125 \% RDF+ foliar spray of } \\
\text { micro nutrient @ } 250 \mathrm{~g} \mathrm{ha}^{-1} \text { at } 25 \\
\text { \& } 45 \text { DAS }\end{array}$ & 19.49 & 992.33 & 886.16 & 87.21 & 5.8 & 2062.88 & 3397.25 \\
\hline $\begin{array}{l}\text { T10-150 \% RDF + foliar spray } \\
\text { of micro nutrient @ } 250 \mathrm{~g} \mathrm{ha}^{-1} \text { at } \\
25 \& 45 \text { DAS }\end{array}$ & 20.85 & 1040.65 & 925.21 & 88.88 & 5.9 & 2195.3 & 3556.48 \\
\hline S. Ed & 0.40 & 20.02 & 16.02 & 0.53 & 0.01 & 50.02 & 69.22 \\
\hline $\mathrm{CD}(\mathrm{P}=\mathbf{0 . 0 5})$ & 0.89 & 40.25 & 32.64 & 1.18 & 0.03 & 103.00 & 140.21 \\
\hline
\end{tabular}

$\mathrm{RDF}=$ recommended dose of fertilizer DAS= days after sowing

$\mathrm{N}=$ nitrogen $\quad \mathrm{P}_{2} \mathrm{O}_{5}=$ phosphorus

$\mathrm{K}_{2} \mathrm{O}=$ potash 
Table.3 Effect of micro nutrient management in hybrid sunflower on quality parameters and returns

\begin{tabular}{|c|c|c|c|c|c|c|c|}
\hline TREATMENTS & $\begin{array}{l}\text { Harvest } \\
\text { index }(\%)\end{array}$ & $\begin{array}{l}\text { Oil } \\
\text { content } \\
(\%)\end{array}$ & $\begin{array}{l}\text { Oil yield } \\
\left(\mathrm{kg} \mathrm{ha}^{-1}\right)\end{array}$ & $\begin{array}{l}\text { Cost of } \\
\text { cultivation } \\
\text { (Rs) }\end{array}$ & $\begin{array}{l}\text { Gross } \\
\text { income } \\
(\mathbf{R s})\end{array}$ & $\begin{array}{l}\text { Net } \\
\text { income } \\
\text { (Rs) }\end{array}$ & BCR (Rs) \\
\hline T1- Control & 31.64 & 40.02 & 300.15 & 11550 & 15012 & 3552 & 1.30 \\
\hline $\begin{array}{l}\text { T2- } 100 \% \text { RDF }\left(60-90-60 \mathrm{~kg} \mathrm{ha}^{-}\right. \\
\left.{ }^{1} \mathrm{~N}^{-} \mathrm{P}_{2} \mathrm{O}_{5} \text { and } \mathrm{K}_{2} \mathrm{O}\right)\end{array}$ & 35.84 & 41.52 & 619.32 & 18050 & 30826 & 12776 & 1.70 \\
\hline T3- 125\% RDF & 36.3 & 41.78 & 673.01 & 19675 & 34357 & 14682 & 1.74 \\
\hline T4- $150 \%$ RDF & 36.61 & 41.97 & 721.92 & 21300 & 40289 & 18989 & 1.89 \\
\hline $\begin{array}{l}\text { T5- } 100 \% \text { RDF + soil } \\
\text { application of micro nutrient @ } \\
20 \mathrm{~kg} / \mathrm{ha}^{-1}\end{array}$ & 36.92 & 42.2 & 772.53 & 20250 & 43321 & 23071 & 2.13 \\
\hline $\begin{array}{l}\text { T6-100\% RDF + soil } \\
\text { application of micro nutrient @ } \\
20 \mathrm{~kg} / \mathrm{ha}^{-1}\end{array}$ & 36.93 & 42.34 & 785.87 & 21875 & 48320 & 26445 & 2.20 \\
\hline $\begin{array}{l}\text { T7-100 \% RDF + soil } \\
\text { application of micro nutrient @ } \\
20 \mathrm{~kg} / \mathrm{ha}^{-1}\end{array}$ & 37.74 & 42.62 & 868.05 & 23500 & 58790 & 38290 & 2.50 \\
\hline $\begin{array}{l}\text { T8-100 \% RDF + foliar spray of } \\
\text { micro nutrient @ } 250 \mathrm{~g} \mathrm{ha}^{-1} \text { at } 25 \\
\text { \& } 45 \text { DAS }\end{array}$ & 36.94 & 42.45 & 798.7 & 18550 & 45760 & 27210 & 2.46 \\
\hline $\begin{array}{l}\text { T9-125 \% RDF+ foliar spray of } \\
\text { micro nutrient @ } 250 \mathrm{~g} \mathrm{ha}^{-1} \text { at } 25 \\
\text { \& } 45 \text { DAS }\end{array}$ & 37.78 & 42.79 & 882.7 & 20175 & 59870 & 39695 & 2.92 \\
\hline $\begin{array}{l}\text { T10-150 \% RDF + foliar spray } \\
\text { of micro nutrient @ } 250 \mathrm{~g} \mathrm{ha}^{-1} \text { at } \\
25 \& 45 \text { DAS }\end{array}$ & 38.16 & 43.0 & 943.97 & 21800 & 68025 & 46225 & 3.12 \\
\hline S. Ed & 0.07 & 0.06 & 12.01 & & & & \\
\hline $\mathrm{CD}(\mathrm{P}=0.05)$ & 0.16 & 0.15 & 25.13 & & & & \\
\hline
\end{tabular}

Shivankar et al., (2003) reported there presoaking sunflower seeds with 0.5 per cent $\mathrm{MnSO}_{4}$ solution had beneficial effect on germination, number of filled seeds, 100nseed weight and yield per plant. Foliar application of micro nutrient particularly $\mathrm{Zn}$ and $\mathrm{Mn}$ in small amounts had significant positive effect on 1000 seed weight, plant height, biological yield, grain yield, harvest index and oil content of sun flower (Babaeian et al., 2011; Kohnaward et al., 2012). Among all the treatments, the application of $150 \% \mathrm{RDF}+$ foliar spray of micro nutrient @ $250 \mathrm{~g} \mathrm{ha}^{-1}$ at $25 \& 45$ DAS $\left(\mathrm{T}_{10}\right)$ significantly increased the 
yield attributes of sunflower viz., capitulum ${ }^{-1}$, total number of seeds capitulum ${ }^{-1}$, number of filled seeds capitulum ${ }^{-1}$, percentage of filled seed capitulum ${ }^{-1}$ and test weight. This could be due to synergetic and accumulative effect of the integration of RDF and micronutrient on sunflower. The increase capitulum ${ }^{-1}$ diameter could be to better nutrient supplement and consequently efficient translocation of assimilates to the developing sink (capitulum ${ }^{1}$ ). The higher dose of NPK significantly recorded higher head diameter (Table 2).

The present results are in conformity with the earlier reports of Reddy and Raja Reddy. (2001) in sunflower crop. Similar report conformity with the Pragathi Kumar et al., (2004). The foliar applied micronutrient increased photosynthetic and enzymatic activity and an effective translocation of assimilate to reproductive parts result in higher yield (Sarkar and Mallick, 2001).

\section{Quality parameters and economics}

Seed quality parameters were also differed significantly due to treatments. The different nutrient management practices shown significant different in oil content of hybrid sunflower however, the nutrient supply system consisting of application of 150 \%RDF+ foliar spray of micro nutrient @ 250 $\mathrm{g}$ ha $^{-1}$ at $25 \& 45$ DAS $\left(\mathrm{T}_{10}\right)$ numerically registered the maximum oil content of 43.0 per cent during the crop season. This was followed by treatments $\left(\mathrm{T}_{9}\right) 125 \% \mathrm{RDF}$ +foliar spray of micro nutrient @ $250 \mathrm{~g} \mathrm{ha}^{-1}$ at $25 \& 45$ DAS (42.79 per cent) during the crop season. Which was on par with $\left(\mathrm{T}_{7}\right)\left(\mathrm{T}_{8}\right)\left(\mathrm{T}_{6}\right)$ $\left(\mathrm{T}_{5}\right) \quad\left(\mathrm{T}_{4}\right) \quad\left(\mathrm{T}_{3}\right) \quad\left(\mathrm{T}_{2}\right)$. Whereas the treatment control 40.02 per cent during the crop season. Oil yield gross income, net income and benefit cost retia recorded $68,025 \mathrm{ha}^{-1}, 46225$ $\mathrm{ha}^{-1}$ and 3.12 respectively) which was on par with $\left(\mathrm{T}_{9}\right)\left(\mathrm{T}_{7}\right)\left(\mathrm{T}_{8}\right)\left(\mathrm{T}_{6}\right)\left(\mathrm{T}_{5}\right)\left(\mathrm{T}_{4}\right)\left(\mathrm{T}_{3}\right)\left(\mathrm{T}_{2}\right)$. The improvement in seed quality parameters may be attributed to the fact that nutrition of the mother plant which reflects on seed quality due to accumulation of higher quantities of seed reserves like protein and carbohydrates (Table 3). Application of borax significantly recorded maximum oil content, oil yield and protein content of sunflower over control. Zahoor et al., (2011) and Parameswari et al., (2012) observed that foliar application of borax along with $60 \mathrm{~kg} \mathrm{~N}$ $\mathrm{ha}^{-1}$ significantly recorded higher oil content protein content in sunflower over control. Mohsen Rajabi (2013) reported that foliar application of $\mathrm{Zn}+\mathrm{Mn}$ significantly recorded higher oil content and oil yield of sunflower over other treatments. Availability and steadily supply of nutrient to the sunflower crop particularly of the later stages could have resulted in higher oil content can be recorded with the application of $150 \% \mathrm{RDF}+$ foliar spray of micro nutrient @ $250 \mathrm{~g} \mathrm{ha}^{-1}$ at $25 \& 45$ DAS $\left(\mathrm{T}_{10}\right)$. This could be due to higher growth components and nutrient uptake as well as seed filling percentage. Several workers have been reported the beneficial effect micro nutrient along with recommended fertilizer in increasing the oil content and oil yield of sunflower seed (Nandagopal et al., 2003a; Reddy et al., 2007; Mehmet sincik et al., (2013).

\section{References}

Ali, A.A.G.and S.A.E. Mowafy. 2003. Effect of different levels of potassium and phosphorus fertilizers with the foliar application of zinc and boron on peanut in sandy soils. Zagazig J. Agric. Res., 30: 335-358.

AyadShankerT.Saad and Mohammed. 2011. Effect of different levels and timing of boron foliar application on growth, yield and quality of sunflower genotypes (Helianthus annus L.). Mesopotamia J. Agric., 39: 16-26.

Babaeian, M., I.Piri, A.Tavassoli, Y. 
Esmaeilian and H. Gholami. 2001. Effect of water stress and micronutrients (Fe, $\mathrm{Zn}$ and $\mathrm{Mn}$ ) on chlorophyll fluorescence, leaf chlorophyll content and sunflower nutrient uptake in Satsang region. Afr.J. Agric.Res., 6: 3526-3531.

Chinnamuthu, C.R., A.S. Venkatkrishnan and P. Manickasundaram. 2004. Effect of proceeding kharif legumes of NPK on the succeeding rabi sunflower (Helianthus annus L.). J. oil seeds Res., 21: 82-85.

Dordas, C. and P.H. Brown. 2001. Permeability and the mechanism of transport of boric acid across the plasma membrane of (Xenopuslaevis) Oocytes J. Bio Trance Elements Res., 127-139.

FaziusSalehin and ShahedurRahman. 2012. Effect of zinc and nitrogen fertilizer and their application method on yield and yield components of Phaseolus vulgaris L. Agric Sci., 3:9-13.

Horrison, M.D., C.E. Jones and C.T. Doremon. (1999). Copper chaperones function structure and copper-binding properties. JBIC, 4, 145-153.

Jambunathan, R., S.M. Raja and S.P. Barde. 1985. Analysis of oil content of groundnut by nuclear magnetic resonance spectrometry. J. Sci. Food Agri., 36:162-166.

Khurana, N. and C. Chartterjee. 2001. Influence of variable Zinc and yield, oil content and physiology of sunflower. Soil sci. Plant Anal., 32:3023-3030.

Khonaward, P., J. Jalilian and A. Pirzad. 2102. Effect of foliar application of micro-organisms on yield and yield components of safflower under conventional and ecological cropping systems. Intern. Res. J. Applied and Basic Sci., 3:1460-1469.

Loomis, W.D and R. W. Drust. 1992. Chemistry and Biology of boron Bio. factors 3: 229-239.
Mehmet Sincik, AbdurrahimTanjuGoksoy and Dogan. 2013. Response of sunflower (Helianthus annus L.) to irrigation and nitrogen fertilization rates. Zemdirbyste-Agric., 100: 151158.

Mohsen Rajabi, Moslem Fetri, Mohammand Eghbal Ghobadi, Mohammand HadiParajiArman. 2013. Foliar Application of $\mathrm{Zn}$ nana $\mathrm{Mn}$ fertilizers on yield and yield components of safflower (Carthamus tintorius L) cultivars. Int. J. Agric. Crop Sci., 5: 718-722.

Muhammad Tahir, Sharjeet Ashraf and Muhammad Ibrain. 2013. Effect of foliar application of boron on yield and quality of sunflower (Helianthus annus L) Crop \&envoi., 4: 23-25.

MuraliArthanari, P., T.N. Balasubramanaian and M. Mohamad Amaullah. 2009. Impact of climate and nutrient management on yield components and yield of sunflower (Helianthus annus L.) American- Eurasian J. Sustainable Agric., 3: 13-16.

Nandagopal, A., K.S. Subramanian, R. Jayakumar and A. Balasubramanian. 2003a. integrated nutrient management for hybrid sunflower (Helianthus annus L.). Madras Agric. J., 90: 66-73.

NursatJabeen and Rafiq Ahmed. 2001. Effect of Boron and Manganese on growth and biochemical activities in sunflower under saline conditions. Pak. J. Bot., 43: 1271-1282.

Parameswari, Y.S., A. Srinivas and Mandal Moguluru. 2012. Yield and yield content of sunflower (Helianthus annus L) as influenced by nitrogen and boron nutrition. Crop Res. 44: 311-313.

Pragathi Kumar, CH., A. Latchanna and V. Sathyanarayana. 2004. Effect of biofertilizer on growth and yield of sunflower. The Andhra J., 55:277-280.

Reddy Ramu P.V.R.M. and C.K. Raja Reddy. 
2001. Nutrient uptake pattern of sunflower as influenced by integrated nutrient management. The Andhra J. Agric. Sci., 49: 41-44.

Reddy, B.N., S.N. SudhakaraBabu and K. Bhanurekha. 2007. Productivity and nutrient uptake of sunflower (Helianthus annus L.) as influenced by site specific integrated nutrient management of Alfisols. J. Oilseeds Res., 24: 331-333.

Renukadevi, A., P. Savithiri and K. Andi. 2004. Residual effect of sources and level of boron application on green gram (Vigna radiata) in sunflowergreen gram cropping sequence. Madras Agric. J.9: 394-398.

Sarkar, D., B. Mandal and M.C Kundu. 2007. Increasing use efficiency of boron fertilizers by Re scheduling the time and methods of application for crops in India.Plant Soil, 301: 77-85.

Sarkar R.K. and R.B. Maliick. 2009. Effect of nitrogen, Sulphur and foliar spray of nitrate on performance of spring sunflower (Helianthus annua L.) Indian J. Agric. Sci., 986-990.

Shivankar, R.S., D.B. Deore and N.G. Zode. 2003. Effect of pre-sowing seed treatment on establishment and seed yield of sunflower. J. Oilseeds Res., 20: 299-300.

Sonnad, J.S., Raveendran, N. Aijan and K.N. Selvaraj. 2011. Growth analysis of oil seed crops in India during pre and post WTO periods. Karnataka J. Agric. Sci., 24: $184-187$.

Verma, S.C. 1973. Agronomy of new plant types. Tara publications, Varanasi,32.

Venkata Krishnan, A.S. and N. Balasubramanian. $1996 . \quad$ Yield maximization in sunflower. Madras Agric. J., 83: 791-792.

Zahoor, R. S.M.A. Basra, H. Munir, M.A. Nadeem and S. Yousat. 2011. Role of boron in importing assimilates portioning and achene yield in sunflower. J. Agric. Soc. Sci. 7: 160168.

\section{How to cite this article:}

Ramesh, V., J. Manjunath, M. Saravanaperumal and Reddy Bheemanna. 2019. Effect of Micro Nutrient Management in Hybrid Sunflower on Growth and Yield. Int.J.Curr.Microbiol.App.Sci. 8(06): 1222-1231. doi: https://doi.org/10.20546/ijcmas.2019.806.149 